\title{
Massimiliano Spotti* \\ Interactional regimes of sociolinguistic behaviour: An ethnographic exploration of the scales at play across the spaces of an asylum-seeking centre
}

\author{
https://doi.org/10.1515/applirev-2019-0141
}

\begin{abstract}
Drawing on the notion of sociolinguistic scaling, the present contribution argues for an understanding of an asylum-seeking centre as a unit of inquiry in which sociolinguistic repertoires are played out during intercultural communicative encounters. The contribution shows how the centre's spaces encapsulate time- and space-bound interactional regimes and language hierarchies. Taken as such, the different rooms that make up the centre, e. g. the office, the activity room and the corridor, all may seem neutral spaces where the daily lives of people unfold. However, each of these spaces invites, allows and dismisses various interactional sociolinguistic regimes that lead to micro-practices of inclusion and exclusion. The article concludes with a consideration on whether the homogeneous category 'newly arrived migrant in need of civic integration' authored by many governments across Europe, should not be re-evaluated, in light of the affordances of sociolinguistic scaling and digital literacy potentials that each of these newly arrived individuals have in stock in their repertoires.
\end{abstract}

Keywords: domain, asylum seekers, space, multilingualism, understanding, metapragmatics

\section{Introduction}

Inasmuch as movement of goods, knowledge and capital is a key feature of contemporary globalised discourses across the EU nation-states, movement has always been part of the conditio humana, even before this contemporary globalised moment. More prominently than ever, however, the movement of people who (try to) set foot on EU soil contributes to the construction of

\footnotetext{
*Corresponding author: Massimiliano Spotti, Department of Culture Studies, Tilburg University, Building D, Room 219, Tilburg, 5000 LE, The Netherlands,

E-mail: m.spotti@tilburguniversity.edu

https://orcid.org/0000-0003-2907-2174

Ә Open Access. (c) 2020 Spotti, published by De Gruyter. (cc) BY-NC-ND This work is licensed under the Creative Commons Attribution-NonCommercial-NoDerivatives 4.0 License.

Published online August 31, 2021
} 
superdiversity, that is to the diversification of an already consolidated diversity that had settled in Europe during the twentieth century (Vertovec 2007, Vertovec 2019; Blommaert and Rampton 2011). Again, more prominently than ever, this condition of superdiversity is cause of heated public and political debates (see Spotti 2018, Spotti 2019). These debates all seem to postulate one thing: migration of a certain type is a detrimental phenomenon for societies. Together with migration, in fact, comes diversity and within diversity - presupposing that the following are all countable definable and discrete objects we find diversity of cultures, of languages, of customs, of childrearing practices, of gendered relations and through that the possible destabilisation of a presupposed national order. As a result of this, governmentally authored discourses across the EU present two types of individuals. One type refers to individuals that are favoured by migration authorities. Favoured individuals have clear cut legal status, e.g. expats, foreign students and knowledge migrants. They very often hold either one or more tangible proofs of identity or proofs of educational qualifications, which grant them to have self-sustaining societal positions that do not appear to impinge on the precarious economic well-being of EU societies. Further, this first set of people turn out to be deeply entrenched in (digitally) mediated communication; they bond and bridge their social relations networks through socio-technological platforms and are able to participate in society through an array of (often formally certified) digital literacy skills that allow them to be part of multiple overlapping transnational networks of socialisation (see Maric and Spotti 2016). At the other end, in contrast, we find individuals whose movement has happened through somewhat less orthodox means of mobility, e.g. migrant labourers working illegally on the black market, asylum seekers, refugees, illiterate and low literate migrants. These individuals tend to be relegated to essentialist identity categories by policy documents and their implementation, often glossing them over with the category 'in need of civic integration'. With this all as our backdrop, an asylum-seeking centre functions as an important case in point here. The centre is a place filled by mobile people brought there by events happening many hundreds or thousands miles away who have different degrees (often informal, unrecognised and uncertified) of multilingual and digital repertoires that they employ on a daily basis while awaiting - in this waiting room of globalisation - for their legal status to be determined by the state (see also Dattatreyan 2015).

Against this background, drawing on the notion of sociolinguistic scaling, the present contribution focuses on the second set of mobile people mentioned above. In doing so, it argues for an understanding of an asylum-seeking centre as a unit of inquiry in which sociolinguistic repertoires 
and language users' identity categorisation (Spotti and Blommaert 2017) are played out during intercultural communicative encounters. The contribution aims to show how the centre encapsulates time- and space-bound interactional regimes and language hierarchies. Taken as such, the different rooms that make up the centre, e. g. the office, the activity room and the corridor, to name but a few, all may seem neutral spaces where the daily lives of people unfold and tick together the way they do. However, each of these spaces invites, allows and dismisses different interactional sociolinguistic regimes. These regimes show perceptions of what counts not only as the right language to use when, where and with whom; rather, they also show how these language users manage to move across scales during the interactional process of meaning (un)making. Understanding practices of speakerness, the use of sociolinguistic repertoires and the rise and fall of the status of speakers during communicative encounters therefore requires 'an understanding of the connections between different centres [of normativity] and their indexical orders' (Blommaert et al. 2005: 207). What counts as 'good' communicative behaviour and 'acceptable' semiotic identity display in a place where those who inhabit the centre hang out spending their spare time watching videos on their mobile phone devices, it could be subsequently disqualified in another space where the valid sociolinguistic and semiotic norms are of a different scale level, e. g. that of the state and of its handed-down policies of integration, mostly based on language learning and on the learning of cultural norms and values.

My argument unfolds as follows. Given the centrality of the notion of space, I draw readers' attention to theories of space and to the notion of sociolinguistic scales. I then draw on two ethnographic vignettes taken from a data corpus I collected during a large ethnographic interpretive inquiry focused on the implications of digitalisation for asylum seeking practices and on the meaning attached to being an asylum seeker in times of superdiversity. By doing so, I tackle the negotiation of sociolinguistic regimes across two 'key incidents' (Kroon and Sturm 2007) that happened in an asylumseeking centre located in Flanders, the Dutch-speaking part of Belgium. My contribution concludes by considering whether the policy-driven category 'newly arrived migrant in need of civic integration' remains a valid category for addressing and talking about the people who inhabit this centre or whether, on the basis of a more scale-sensitive analysis, we should start looking at the transformative potential that allows digitally literate mobile subjects at a disadvantage to move beyond this homogenising policy-driven discursive categorisation. 


\section{Moving from the scientification of language towards the socialisation of language}

Let us begin with the following statement: the assemblage of what makes things and people, within a given socio-cultural space, all tick together in the way they do, i. e. society, is an extremely hard thing to understand. Following the scientification of language in the late nineteenth century, linguists taught themselves to abandon society and focus on 'language' alone. In concreto, this meant that those interested in language would have channelled much, if not all, of their attention on the phonological, morphological and syntactic structures that make up 'a language'. The consequences of this selective attention, in turn, had been the isolation of the study of language from its societal use and more specifically, a divide between the study of language forms and the consequent mapping of these forms onto specific functions. These form-function mappings were then imagined to contribute to the construction of social meaning.

In sharp contrast to this rather opaque canvas depicting language and society as odd bedfellows, the study of language and society and, more precisely, the study of language as a social phenomenon is much indebted to the work of Joshua Fishman and to the later developments by Gumperz and Hymes (1964, 1986). Dealing with Fishman's (1971) work first, we see that the basis for the sociology of language rests on the foundation of the use of language in concomitance with the social organisation of behaviour across societal domains. It is, again, thanks to Fishman that, from a descriptive sociology of language whose basic task it was to show how social networks and speech communities do not display either the same language usage or believe the same things about language, scholars have moved towards a more dynamic sociology of language. The main goal of the latter has been to unravel both why and how two once similar networks or communities have arrived at a quite different social organisation of language use and show a quite different behaviour towards language, whether factual or ideological. Although Fishman's dynamic approach to the sociology of language touches on the issue of repertoire change, much of his initial work remains anchored in a sociolinguistics of spread, stable and unstable bilingualism and the construction and revision of writing systems.

It is with the work of John Gumperz that the study of language and society underwent a total reshaping. In the work that was seminal for the discussion of the concept of a "speech community", Gumperz (1968) showed that while a named language was a category for those who studied language, it was not so for language users. Starting with communicative practices, functions and 
repertoires, rather than focusing on structuralist grammatical systems, Gumperz found that the study of language went beyond approaches that described how linguistic knowledge is structured in systematic ways. Rather, the core notions in Gumperz's approach to the study of language became interpretation, understanding, meaning and, with that, meaning-making while engaged in interaction.

This all required a new level of sociolinguistic analysis (Gumperz 1971: 343) that had as its focal point how interpretation and understanding, rather than 'language', are intertwined with the construction of shared common grounds. This became a forerunner of the Silversteinian 'total linguistic fact' (1985) that, as Wortham states, includes the analysis of form, use, ideology and domain (Wortham 2008: 83). Most sociolinguistic analysis, by now, has taken on board that any language problem is concomitant with a societal problem, and that in order to have a full-fledged sociolinguistic analysis of a societal problem, we ought to pay attention to the in situ interactional micro-fabrics of sociolinguistic encounters.

\section{Sociolinguistics domains, scaling and its conceptual implications}

The language and society binomium above highlights a recurrent twitch in the eye of sociolinguistics in that societies do continuously change (Appadurai 1996) and with them sociolinguistic theorising is called, or even compelled, to (re-)invent its conceptual armour and its analytical lenses (Blommaert and Rampton 2011). While doing so, notwithstanding the risk of stepping into diatribes around 'the barren verbiage' of language (Makoni 2012) and around the branding of sociolinguistic theorising (Pavlenko 2018), sociolinguistics has to engage with metaphors that serve the purpose of helping the analyst imagine and, through that, understand the changing nature of contemporary globalised societies and scrape beneath the surface of their normalcy, i.e. beneath the normalcy embodied in their cultural ecologies. The notion of scales and with that its gerundive form, i. e. scaling, do seem a poignant embodiment of a sociolinguistics that wishes to re-invent itself (see also Blommaert this volume). Given that $\mathrm{f}$ this special issue goal is indeed to dwell on what scaling is and how it can best serve the regained uncertainty in sociolinguistics and applied linguistics that Gumperz had already vented in his seminal work, I first focus on the concept of space, 
or to use a more refined term, space as sociolinguistic domain. From there, I make suggestions on how scaling could potentially result in a viable set of metaphors for sociolinguistic theorising, although sociolinguistic analysis must beware the danger of being trapped by the very same tropes it produces, thus leading to the reification of scales as entities that can be 'jumped' or 'leaped' as if they were ready-made tangible objects.

Henry Lefebvre (1991) views space as a social product that masks the contradictions of its own production. Further, in an effort to link human agents and spatial domination, Pierre Bourdieu (1977) focuses on the spatialisation of everyday behaviour and how the socio-spatial order of behaviour is translated into bodily experience and practices of expression. Bourdieu - and social scientists will build heavily on this (see Scollon and Scollon 2003; Blommaert and Huang 2010) - proposes the concept of habitus, a generative and structuring principle of collective strategies and social practices that makes new history while being a product of history itself. Michael Foucault, in his seminal work on the prison (1977) and in a series of interviews and lectures on space (1984), examines the relationship of power and space by positing architecture and the use of space as a technology of the government that tries to regulate the bodies of those who are in its immediate detention. The aim of such a technology, in Foucault's wording, is to shape 'a docile body' (Foucault 1977), an almost subjugated subject whose body can be mastered due to enclosure and the organisation of individuals in space. Building on this, de Certeau (1984) sets out to show how people's ways of doing things make up the means by which users re-appropriate space organised by techniques of socio-cultural production. These practices are articulated in the fine-grained details of everyday life and used by groups or individuals already caught in the nets of discipline, though in his work spatial practices elude the (implicit) planning of government control. Drawing again on De Certau (1984), power in space is embedded through territorial delimitation and boundaries in which the weapons of 'the strong' are classification, delineation and division - the so called 'strategies' of spatial domination - while 'the weak' use furtive movements' shortcuts and routes also addressed as 'tactics'. The latter is used to contest, negotiate or even subvert spatial domination and all that comes along with it that is the normativity of doing things as prescribed by the one in power (De Genova 2002). Understanding multilingualism and the deployment of sociolinguistic repertoires in the spaces of an asylum-seeking centre requires therefore an understanding of the connections between spaces, the bodies that populate them and the sociolinguistic scales at play within an established set of institutional practices. 


\section{The asylum-seeking centre, its 'guests' and its domains}

This study, part of a larger ethnographic interpretive inquiry aimed at unravelling the implications of socio-technological means of socialisation in the lives of asylum seekers, builds on data collected through three rounds of fieldwork between 2012 and 2014 at an asylum-seeking centre in Flanders, the Dutch speaking part of Belgium. The project combines insights, methods and epistemological stances stemming from linguistic ethnography (Creese and Copland 2014; Rampton et al. 2007) and socio-culturally rooted discourse analysis (Gee 1999). In both frameworks, the Gumperzian assumption that the way individuals speak as well as speak about things reflects their culturally embedded understanding of the human beings around them and their perception of the world is made explicit and showed in its empirical tangibility. The data from which the two ethnographic vignettes of the present contribution draw upon were collected in October 2013, during my first round of fieldwork at the centre. My positioning there was that of a buffer between 'the assistants', i. e. staff members regularly employed by the centre but who did not play any role - at least officially - in the recognition or dismissal of the applicants' claims; the volunteers who were coming in weekly for an array of activities and the 'guests', a term being used by the director for addressing all the residents of the centre. When asked by 'the guests' who I was and what I was doing there, I candidly explained to them that I was writing a book about what it means to be an asylum seeker and what asylum seeking implies, and that I was interested in their daily lives. All the participants embraced my interest and, although they were given the opportunity to opt out of being included in the study, none of them did so. Possibly because I myself am not a native speaker of Dutch with a national background other than the mainstream one, they reacted enthusiastically as they imagined that another foreigner who had somehow gained a voice among the authorities there at the centre was hosted to write about their lives, their experiences at the centre and beyond that, during their individual asylum seeking routes. Living side by side with them, having breakfast with them, talking to them while drinking endless cups of sweetened Afghani tea, following their doings that ranged from Dutch language lessons to knitting lessons, to gym activities to simply smoking cigarettes together in the evening, all amounted towards a time of deep hanging out and trying to scrape beneath the surface of the centre's socio-cultural and sociolinguistic ecology as well as beneath the surfaces of normalcy that wrap their daily living. 
Rather than using either nationality or ethnic grouping as criteria for assigning rooms, the then director of the centre had opted - where he and his team members felt it not to be a risk - to put together people of different ethnic, linguistic and religious backgrounds. During this round of ethnographic fieldwork, the centre catered for 61 'guests'. They appear to be a multi-ethnic and multilingual group of migrants, yet still rather homogenous regarding further aspects of diversity, such as age group, gender and legal status. Following the information gathered at the centre during their intake talks, guests were from the following (often self-claimed) national backgrounds: 13 from Afghanistan; twelve from 'The Russian Federation' - mostly from Armenia and Chechnya nine from Guinea Conakry; nine from Bangladesh; seven from the Democratic Republic of Congo. Following the unofficial statistics kept at the centre, the remaining eleven guests originated from what had been categorised as 'other' (anders). These were respectively two from Senegal, one from Somalia, one from Togo, three from China (Tibet), one from Albania and one from Ukraine. 40 of these guests were male, 21 were female. Eleven of them fell under the category unaccompanied minors, though three of them still needed to give age proof through bone scans. Only two guests had passed their 50s, confirming the trend - pointed out by the centre director - that seeking for asylum is mostly a practice for either unaccompanied minors or young (often male) applicants ranging from their early 20s to their late 30s. All names given in this case study are pseudonyms so to grant participants protection and privacy. Although video recording was not possible due to the resistance of some of the volunteers and due to the ethical issue of wanting to protect the guests from being made recognisable, audio recordings were always permitted. When I felt that a conversation we had was particularly interesting, I asked them whether they would have any objections to being taped, else I relied on my field notes alone.

\subsection{The sociolinguistic context of the study}

Following the Federal measures put in place for newly arrived migrants filing an asylum seeking application for refugee status, the institutional obligations of the centre towards the guests and their well-being consisted in providing them with a roof, a bed and food for their daily sustainment. Activities aimed at introducing the guests to the norms and values of mainstream Flemish society do not fall under the basic provision system. Notwithstanding, the centre's director and deputy director saw the centre as the first opportunity for the guests to mingle within the local community. As a result, a number of activities had been set up. 
Among these were knitting lessons, growing vegetables and exchanging them at the local market, as well as learning Dutch as a second language (L2) once a week for one and a half hours. Although not directly falling under Federal regulations, the centre is further seen as a space heavily imbued in a Flemish political discourse that extensively and explicitly predicates the mastering of Standard Dutch as key to newcomers' integration in Flemish society (Sierens 2006; Smet 2011). While the sociolinguistic landscape present on the centre's walls displayed an array of languages and scripts mastered, or at least familiar to the guests, the utterance 'in het Nederlands, alsjeblieft' ('in Dutch please') happened to be used by most of the assistants when guests used English or French in the office asking for something that could range from information about their lawyer appointment to requesting food that they had bought and stored in the common fridge. When a Dutch-only interaction was too difficult for the guests, then English first and French second and where possible other languages like Russian and Arabic would have been employed by the assistant on duty. Aside from these sporadic official interactional encounters at the office where Dutch was often instated of the role of 'official' language when talking to the members of staff, the centre had many places either with no clear-cut sociolinguistic normativity in display or where sociolinguistic normativity could vary according to the time of the day in which one would enter them.

In what follows, I focus on two of the domains I have singled out because of the relevance they have had during fieldwork. The first is the activity room, a large rectangular room with mobile desks and a storage where several voluntary based activities would take place, among which we find the non-regular Dutch as L2 classroom. This domain is a physical space which appears to be used for multiple purposes, thus, changing its socio-spatial configuration and its sociolinguistic interactional regimes depending on the usage. The second domain is made of the three steps at the end of a blind corridor on the centre's ground floor. This domain is a physical space which came across as having fully changed in its purpose and functionality, highlighting the interactional offlineonline nexus present at the centre.

\subsection{Metapragmatic evaluations: 'Beautiful languages but they are no language, really'}

At the centre, the teaching of Dutch as L2 was taken care of by an elderly lady on a pension with a background in teaching. We will call this teacher Frida, it being a pseudonym to protect her privacy. In 2013, Frida's commitment to the centre had spanned a number of years and she claimed to enjoy what she did, 
given that at her age: 'er zijn mensen die het leuk vinden om te gaan koffiedrinken, ik vind mensen leuk dus daardoor ben ik hier' (there are people who like to drink coffee while I like people, so that's why I do it) (Interview Frida). Once a week, Frida teaches Dutch as L2 for one hour using the didactic resources that she sees most fitting to the needs of her students, who have varying degrees of literacy and competence in Dutch. The room in which she teaches has a number of desks and a whiteboard on which guests wrote up their thoughts or poems. The guests were not compelled to attend Frida's class. Rather, they were free to walk in and out at any time during class, as long as they made sure that they are no bother to those who have been attending class from its start. In what follows, I focus on a classroom episode in which Frida teaches Dutch vocabulary. We then move onto Frida's metapragmatic judgments about her students' sociolinguistic repertoires and literacy skills. It is October 10, 2013 and the class was scheduled to start at 13:00 sharp. At 13:03, the lesson opens as follows:

01 Armenian man: if you find yourself [...] from my room an'

02 Frida: niet! vandaag geen engelse les, he'? vandaag nederlandse les, hey? oke'? dus we starten op bladzijde zes. iedereen heeft een kopie?

[Don't! Today no English lesson, right? Today Dutch lesson, right? Okay? So we start on page six. Has everyone got a copy?]

After wiping the whiteboard clean and preparing her worksheets for the day, at 13:06 Frida starts reading each word from the worksheet that she is holding while standing on the right hand side of the whiteboard facing her class. The lesson unfolds with the reading of a string of words that Frida's students have as drawings - on their worksheets. As Frida starts, she reads these words slowly and loudly. While she does so, she points at these words on the worksheet. She then comes to reading the following line:

03 Frida: $\quad$ haan [...] jan [...] lam [...] tak [...] een boom [...] (Hen [...] Jan [...] lamb [...] branch [...] one tree [...])

04 Frida: oke' [...] hier is nel, hier, hier, hier, hi[ii]er, hier is nel. nel is naam, naam voor vrouw, fatima, nel, leen, naam voor vrouw.

(Okay [...] here we have Nel, here, here, here, h[ee]re is Nel. Nel is name, name for woman, Fatima, Nel, Leen, name for woman.) 
05 Armenian man: $\quad$ waarom naam voor vrouw mit $\mathrm{zu}$ [uh] klein leter? (Why is name for woman with [uh] small letter?)

06 Frida: dat is basis nederlands, BASIS [Frida onderstreep dit met een hardere toon]. eerst starten wij met de basis, wij lopen niet! wij stappen [...] na stappen wij stappen vlug, daarna gaan wij lopen, dus nu stappen wij [...] maar dat is juist.

(That is basic Dutch, BASIC [Frida stresses this with a louder tone of voice]. First we start with the basics, we don't walk! We make steps, after making steps, we step faster and then we get walking, so now we make steps [...] though, that is right.)

Frida's lesson was meant to increase the vocabulary breadth and - later on - the vocabulary depth of her Dutch as L2 students. In her understanding, this would involve reading aloud clusters of monosyllabic words and then have the student link a word to a picture on the worksheet. Aside from making clear from the very beginning of her lesson that the lesson was about Dutch, in turn 04 Frida stimulates other learning channels to make her students understand what the locative pronoun 'hier' (here) means, elongating the vowel and stressing the $[\mathrm{r}]$ at the end of the word. While doing so, she also points her right finger to the place on the ground where she is standing. The next communicative turn then sees one of her students, who is from Armenia and who had arrived in Germany first before moving to Belgium, asking a legitimate and rather elementary orthographic question why there is a minor-case letter in a proper (female) noun, 'nel'. This remark uttered in Dutch with insertion of the German 'mit' (with) and ' $z u$ ' (to) gives a glimpse of the German this man has picked up during his unrecognised stay in Germany. Most importantly though the question he poses to Frida is a perfectly plausible display of two things. First, it is a reproduction of Frida's foreign talk that she has uttered in line 4 given that - in his question in line 5 - he also omits, as Frida did, the use of the indefinite article next to the word 'vrouw' (woman). Second, aside from the openable choice of using foreign talk in class, his question shows that he is someone who holds basic literacy knowledge in that he knows that proper names should be spelled with an initial that is capital as it happens throughout any writing system that contains upper and lower case letters. Frida's reaction to this remark appears to serve as a reenforcement of her native speaker's authority. She upscales her argument by postulating a simplified learner language register she calls 'basis Nederlands' (basic Dutch), differentiating it from standard or more elaborate Dutch registers. Frida in fact, reiterates firmly, through her loud tone of voice, how she herself 
understands what it means to learn Dutch. This is expressed through a metaphor that sees the identities of her students as people who - alike young children are learning to walk. She does so by drawing on the similitude 'we do not walk, we make steps, after making steps, we step faster, and then we get walking so now we make steps'. Her reaction though is in contrast with the adversative clause in turn 06 when, in response to her student remark about the lack of capitalisation, she utters in a softer tone of voice: 'but that is correct'. In that moment, Frida scales down giving up her display of native speaker authority and admits that her student's observation was actually a valid one.

Furthermore, in the long open-ended interview I conducted with her to gather information on her professional life as well as in order to understand what she thought she was doing while she was teaching, Frida asserted the following:

'ja, als je gaat naar die landen, eh, dat is alles met handen en voeten, eh, daar en hier is het ook zo een beetje.'

(Yes, if you go to those countries, right, it is all hands and feet, right, and here it is also a little bit like that.)

She then added:

'kijk, deze mensen hebben verschillende talen, echt mooie talen hoor, maar ze zijn eigenlijk geen talen, snap je wat ik bedoel?'

(Look, these people have several languages, really beautiful languages, but they are no languages really, do you get what I mean?)

First, Frida holds a conceptualization of her students based on her own experience once she went on holiday abroad. In fact, she bridges the reality of her class with the communication impediments that she had encountered there where she had to communicate 'through hands and feet', possibly although this could fall into speculation, by showing a form of dehumanisation in the language-ideological understanding where languages 'here' are fully formed entities with a grammar and a rationality in usage. Further in the interview, Frida speaks about her students as 'deze mensen' (these people) who have 'verschillende talen' (several languages) pointing at the awareness of sociolinguistic diversity in her students' repertoires. Yet again, in her interview, she disqualifies the languages of her students. For her, the languages of her students are entities that she addresses as 'echt mooie talen hoor' (really beautiful languages) but, through an adversative clause, she adds that: 'ze zijn geen talen' (but they are not languages) emphasised by the use of the 
strengthening adverb 'eigenlijk' (really). Frida's metapragmatic judgement on the languages of her students can be understood as a language-ideologically loaded statement. In fact, stating that someone's language is not really a language opens up a window on a metapragmatically attributive meaning that enregisters her students as members of an arbitrarily formed speech community of users of communicative means that cannot be categorised as languages. The metapragmatically attributed meaning Frida uses can have different explanations. Although speculative in that Frida did not go deeper into her rationale about her own understanding of what (a real) language might be during the retrospective interview, it may be that Frida does address the languages of her students as 'no languages' because these languages are no European languages. This though comes across as peculiar in that the vast majority of her students reported different levels of proficiency in English, Russian, French and German being either products of the colonial past of their countries of origin or languages that they have encountered during their migration trajectory to Flanders. Another reason, subsuming her criteria for assigning to a language the label of being 'no language really', could be a disqualification of her students' languages in that they are not appropriate languages, useful languages or languages that they do not properly master. Yet again, it could also be that Frida's judgment invokes a micro-crystallisation at a lower scale level of a much larger discourse at governance level that back in 2013 was recurrent in the Flemish public and political debate on newly arrived migrants. In fact, the languages that are present in her class are indeed many and are indeed all beautiful, yet again none of them are Dutch, the language that - following the official discourse - students need for their integration in Flemish society.

\subsection{Doing togetherness through YouTube}

This second ethnographic vignette presents my interaction with two young men called Urgesh and Wassif both residing at the centre. Urgesh is of Bangladeshi origin. He reports that he is proficient in Bengali, Panjabi, some Urdu, English and 'beetje beetje Nederlands' (bit bit Dutch). Wassif reports to be of Afghani origin. As he had worked for the Red Cross in Afghanistan, he is proficient in English as he had to learn it for its daily activities with Red Cross members. He further reports that his first language is Dari and that he knows Arabic (in its classical variety) as well as some Dutch. Both Urgesh and Wassif had grown fond of me during my residence at the centre. They had understood that I was not an institutional figure either interested in their residency application or 
someone who could scold them if they did not behave according to the rules. In the evenings, they were eager to talk to me, using their own varieties of English, about their reasons for coming to Belgium, as well as for their expectations for their lives in Flanders. After having listened to their stories, one night during my fieldwork, they wished to show me the power of 'the steps', i. e. the three steps on the ground floor of the asylum-seeking centre. This space was ever so liked by all young guests at the centre because it had the best Wi-Fi reception in the whole building, although this was also available in the far-left corner of the activity room where Frida's lesson had taken place. Given that this time the WiFi connection was to be used for a ludic activity and not for a Skype call home, a socio-technological affordance that during my fieldwork was left to the activity room alone, they told me to go and sit on the three steps with them. Once we had moved there, they asked me whether I liked music. While telling them that I did like jazz, they wished to show me their favourite genre, heavy metal. The dialogue unfolded as follows:

01 Urgesh: look at this sir, look at this.

02 Wassif: these are cool bruv, these are cool.

03 Urgesh: I have seen them on a gig.

04 Wassif: yeah, yeah, look at that, power, broer (brother) Max, puur (pure) power.

(From author's fieldnotes)

In the excerpt above, Urgesh and Wassif are commenting on a Bengali band - called Sultana Bibiana - that plays a cover from the world famous band Metallica. While the streamed video is being broadcasted on Urgesh's phone screen via YouTube, the two young men are convivially commenting on the video. Although mundane and rather short, this exchange - that has been taken straight from my field notes - opens up a window on several scales and within these scales on several issues that have to do with informal language politics and language practices within the spaces of the centre. First, as exemplified by the almost complete absence of Dutch in the exchange, except for the use of the colloquial expression 'broer' (bruv) and 'puur' (pure), this interaction is of a different nature than the one they usually had with centre's assistants where Dutch was requested in order to ask a question and obtain an answer. Second, as it were they who initiated the exchange and asked me to join them on the three steps, they both knew that I would not have asked them to speak to me in Dutch or either use Dutch among each other. Further, the interaction at hand shows that that these men are rather proficient English language users while holding some 
knowledge of Dutch colloquial expressions. For instance, the use of 'Sir' could be pointing at Urgesh's Bengali background and thereby appropriately at the difference in age between me (end of my 30s) and him (end of his 20s), while the more horizontal expression uttered by Wassif doing 'bro-talk' (see also Kiesling 2018) might have been uttered for the purpose of my inclusion in the three steps domain and worked towards establishing masculine jocular solidarity. We can also observe that both Urgesh and Wassif are technoliterate in that they use the internet as a means for accessing pop-culture content via their mobile phones (Velghe 2014), with Urgesh bringing in experiential knowledge from elsewhere when uttering 'I have seen them on a gig', taking on board a position of authority into the immediacy of this spatio-temporal collapse.

Although these data only allow me to provide the reader with a glimpse of evidence that may shed light on the dynamics of togetherness within the centre, I believe the vignette is worth some further considerations on the online-offline nexus. Online streamed video music, and more precisely the heavy metal genre, is in fact the matter of the present conversation at that very moment in that very domain. This though was not a one-off event triggered by the presence of the researcher. Rather, together with online porn, heavy metal music had also been the topic of many of the conversations I overheard taking place on the three steps through whichever sociolinguistic resources were available among young men there at the centre. Through my observations of the activities taking place on the three steps, I had noticed that these recurrent encounters had as their pivotal point masculine popular culture available online. The encounters had one common characteristic. They were not 'big' discourses taking place around the 'serious things' that characterize the lives of the guests at the centre. These being, for instance, either barriers encountered with the Belgian federative juridical system in charge of their claim, or about their future in Flanders, the difficulties encountered in learning Dutch, or - as it had often been reason for confrontation among residents at the centre - their differing ethno-religious backgrounds. Rather, what these two young men in their brief interaction with me did, was to repurpose the three steps to get engaged in a moment in which the deep tangible differences among us three were backgrounded and where the coagulating centre of the encounter is the online environment offered by a mobile phone, its screen, the YouTube channel being used and the music it plays. This space - a physical space apparently fully changed in its purpose and functionality - becomes very intriguing for highlighting the interactional offlineonline nexus present at the centre and for exploring how this has played a role in the guests' lives which, as Blommaert, building on Simmel (1950), exhorts us to do: 
[...] we need to examine these less conspicuous forms of relationships and kinds of interaction, not instead of but alongside the major social formations. We can only get access to the necessarily abstract society by investigating the on-the-ground micropractices performed by its members, taking into account that these micropractices may diverge considerably from what we believe characterizes 'society' and may eventually show complex ties connecting practices and features of social structure. (Blommaert 2017: 8)

\section{Moving beyond the category 'newly arrived migrant in need of integration'}

To understand multilingualism and the deployment of sociolinguistic repertoires in the domains of an asylum seeking centre where different forces are at play across the scales that intersect these domains, it requires also an understanding of the connections between domains, the people who inhabit them and the sociolinguistic practices at play within established interactional orders. As showed in the first vignette, a perfectly plausible display of someone's basic literacy skills is dismissed. This happens although drawing on basic literacy skills had been used to address the student's puzzled feeling when noticing an orthographic peculiarity present on the worksheet used by the teacher. Further, while the sociolinguistic repertoires of these students were multilingual, the voluntary class teacher operates at a different scale level. Although she recognises her students' as having an array of languages, which she reifies as beautiful, her metapragmatic evaluations suggests that these languages do not (really) count as languages. The second vignette focuses on a moment of temporary laddish aggregation around a popular culture expression that features a Bengali band doing a cover of a world famous American band heavy metal band on YouTube. Although the insights drawn from this second vignette should - as Rampton (2014) warns us - be taken with a pinch of linguistic ethnographic salt due to the risk of being blinded by addressing encounters like these as a priori convivial encounters, I nevertheless dare to infer from it the following. What the young men involved in this incident are doing on those steps appears as a coagulation around a socio-technological platform which - as Goebel (2015) points out in his work on knowledging and television representations among young Indonesian students in condition of migration in Japan - helps them construct a scalar sensitive moment of 'doing togetherness'. The interaction becomes thus not just a one-off event, rather it is scale sensitive because, while immerged in the synchronic immediacy of the use of a socio- 
technological platform there and then, it is constructed in the vernacular variety of English and sees also the use of some tokenistic forms of expression in Dutch, which challenges the official monolingual scale that the centre tries to establish within its walls. This vignette could therefore be elected as an instance of the 'sonic scape' (Hankins 2013: 298) that characterizes these three steps as a space within the centre. A scape in which these two young men - in as much as other young male guests observed during my fieldwork there - construct an emotive, albeit transitory, trans-locality that, while lasting for less than the full streamed video clip footage, affords them the possibility to move away from their own positionality which in this case was that of asylum-seeking Bengali and Afghani young men with diverse language competences, uncertain legal statuses and trajectories of migration.

The categories 'newly arrived migrant in need of integration' and 'guests' are used to define the residents of the centre at different scale levels, the first being part of a governmental regulatory discourse, while the second being applied in the immediacy of the centre's environment by the people who work there. Although these two categories are neutrally used as terms for defining someone's status, both of them point towards people that are foreign to national space, in this case Flanders, and whose task is to integrate in Belgian mainstream society. Furthermore, these categories are, both at the governmental as well as at the local level of the centre, often associated with poor educational backgrounds, low levels of literacy skills, lack of digital skills, lack of Dutch language mastering and the like. As I hope to have shown here, by exploring the sociolinguistic repertoires as well as by exploring the online-offline nexus present in these mobile people's lives, there is more to the 'guests' than the lack of civic integration presupposed by the prototypical figure of 'the newly arrived migrant in need of integration'. Such a reified version of the unfavourable mobile subject here thus results as a form of societal imagination that not only appears to be rather odd, given the skills we have seen, but that appears to be in need of a strong revision.

Acknowledgements: This paper is part of a project I have called 'Asylum Seeking 2.0', which kicked off during an invited talk organised by David Bloome at the Center for Video Ethnography and Discourse Analysis, Ohio State University in March 2015. I am grateful to Bessie Dendrinos, Jan Blommaert and Jaspal Singh for commenting on earlier versions of this paper as well as to all those participants who have agreed to share their daily lives with me in this ethnographic enquiry. 


\section{References}

Appadurai, A. 1996. Modernity at Large: Cultural dimensions of globalization. Minnesota: University of Minnesota Press.

Blommaert, J. 2017. Society through the lens of language: A new look at social groups and integration. Working Papers in Urban Language and Literacies. 207.

Blommaert, J., J. Collins \& S. Slembrouck. 2005. Polycentricity and interactional regimes in 'global neighborhoods. Ethnography 6(2). 205-235.

Blommaert, J. \& A. Huang. 2010. Semiotic and spatial scope: Towards a materialist semiotics. Working Papers in Urban Language and Literacies. 62.

Blommaert, J. \& B. Rampton. 2011. Language and superdiversity. Diversities 13(2). 1-21.

Bourdieu, P. F. 1977. Outline of a theory of practice. Cambridge University Press.

Creese, A. \& F. Copland. 2014. Linguistic Ethnography. In K. King, Y. Lai \& S. May (eds.), Research methods in language and education, 339-351. London: Springer.

Da Genova, N. P. 2002. Migrant illegality and deportability in everyday life. Annual Review of Anthropology 31(1). 419-447.

Dattatreyan, E. G. 2015. Social media inspired self-portraits as gallery exhibition in Delhi, India. Visual Anthropology Review 31(2). 134-146.

De Certau, M. 1984. The practice of everyday life. Berkley: University of California Press.

Fishman, J. A. 1971. The sociology of language. An interdisciplinary social science approach to sociolinguistics. In J. A. Fishman (ed.), Advances in the sociology of language, 217-239. Mouton: Berlin.

Foucault, M. 1977. Discipline and punish: The birth of the prison. New York: Vintage Books.

Gee, J. P. 1999. An introduction to discourse analysis: Theory and method. London: Routledge.

Goebel, Z. 2015. Language and superdiversity: Indonesians knowledging at home and abroad. Oxford: Oxford University Press.

Gros, F., F. Ewald, A. Fontana \& A. Davidson. 1984. Michel Foucault - The courage of the truth (The Government of Self and Others II), Lectures at the college de France. London: Palgrave Macmillan.

Gumperz, J. 1968. Types of speech community. In J. A. Fishman (ed.), Readings in the sociology of language, 460-472. Berlin: De Gruyter Mouton.

Gumperz, J. 1971. Language in social Groups. Stanford: Stanford University Press.

Gumperz, J. \& D. Hymes (eds.). 1964. Special issue: The ethnography of communication. American Anthropologist 66(6). 1-186.

Gumperz, J. \& D. Hymes (eds.). 1986. Directions in sociolinguistics: The ethnography of communication. London: Blackwell.

Hankins, S. 2013. Multidimensional Israeliness and Tel Aviv's Tachnah Merkazit: Hearing culture in a polyphonic transit hub. City and Society 25(3). 282-303.

Kiesling, S. F. 2018. Masculine stances and the linguistics of affect: On masculine ease. International Journal of Masculinity Studies 13(3/4). 191-212.

Kroon, S. \& J. Sturm. 2007. International comparative case study research in education: Key incident analysis and international triangulation. In W. Herrlitz, S. Ongstad \& P. van de Ven (eds.), Research on MTE in a comparative international perspective: Theoretical and methodological issues, 99-118. Amsterdam: Rodopi.

Lefebvre, M. 1991. The production of space. Cambridge: Blackwell. 
Makoni, S. 2012. A critique of language, languaging and supervernaculars. Muitas Vazes 1(2). 189-199.

Maric, J. \& M. Spotti. 2016. Immigrant webcommunities: Gateways to transnational social capital. In C. Bernadas \& D. Minchella (eds.), Proceedings of the 3rd European Conference on Social Media, 206-213. London: Academic Publishing.

Pavlenko, A. 2018. Superdiversity and why it isn't: Reflections on terminological innovation and academic branding. In S. Breidbach, L. Kuster \& B. Schmenk (eds.), Sloganizations in language education discourse, 142-168. Bristol: Multilingual Matters.

Rampton, B. 2014. Dissecting heteroglossia: Interaction ritual or performance in crossing and stylization? In A. Blackledge \& A. Creese (eds.), Heteroglossia as practice and pedagogy, 275-300. New York: Springer.

Rampton, B., Maybin, J. \& K. Tusting. 2007. Linguistic Ethnography: Links, problems and possibilities. Journal of Sociolinguistics 11(5).

Scollon, R. \& S. W. Scollon. 2003. Discourses in place: Language in the material world. London: Routledge.

Sierens, S. 2006. Immigratiesamenleving, onderwijs en overheid in Vlaanderen: Een gespannen driehoeksverhouding. In S. Sierens, M. Van Houte, P. Loobuyck, K. Delrue \& K. Pelleriaux (eds.), Onderwijs Onderweg in de Immigratie Samenleving, 9-32. Ghent: Academia Press.

Silverstein, M. 1985. Language and the culture of gender. In E. Mertz \& R. Parmentier (eds.), Semiotic mediation, 219-259. New York: Academic Press.

Simmel, G. 1950. The sociology of Georg Simmel. K. H. Wolff (ed.). Glencoe: The Free Press.

Smet, P. 2011. Samen Taalgrenzen Verleggen. Conceptnota. Onderwijs en Vorming. https://docplayer.nl/10794506-Conceptnota-samen-taalgrenzen-verleggen-versie-22-juli2011.html.

Spotti, M. 2018. 'It's all about naming things right': The paradox of web truths in the Belgian asylum-seeking procedure. In N. Gill \& A. Good (eds.), Asylum Determination in Europe: Ethnographic perspectives, 69-90. London: Palgrave Macmillan.

Spotti, M. 2019. A peek into Salvini's taxonomy of migration. Diggit Magazine. https://www.diggitmagazine.com/column/peek-salvinis-taxonomy-migration.

Spotti, M. \& J. Blommaert. 2017. Bi-multilingualism, globalization and super-diversity - toward sociolinguistic repertoires. In O. García, N. Flores \& M. Spotti (eds.), Oxford handbook of language and society, 161-178. Oxford: Oxford University Press.

Velghe, F. 2014. 'I wanna go in the phone': Literacy acquisition, informal learning processes, 'voice' and mobile phone appropriation in a South African township. Ethnography and Education 9(1). 111-126.

Vertovec, S. 2007. Super-diversity and its implications. Ethnic and Racial Studies 30(6). 1024-1054.

Vertovec, S. 2019. Talking around super-diversity. Ethnic and Racial Studies 42(1). 125-139.

Wortham, S. 2008. Linguistic anthropology of education. Annual Review of Anthropology 37. 37-51. 